\title{
Three Perspectives on the Spiritual Qualities of Music*
}

\author{
Müziğin Ruhani Niteliklerine Yönelik Üç Bakış Açısı
}

\author{
Ekin ÇORAKLI KAHRAMAN ${ }^{1}$ (1)
}

DOI: $10.26650 / C O N S 2020-0010$

* This paper was presented in part at the 26th European Association for Music in Schools (EAS) Conference.

'Doç. Dr., Bolu Abant Izzet Baysal University, Department of Music Education, Bolu, Turkey

\section{ORCID: E.Ç.K. 0000-0001-8372-2751}

Corresponding author/Sorumlu yazar: Ekin Çoraklı Kahraman, Bolu Abant Izzet Baysal University, Department of Music Education, Bolu, Turkey E-mail/E-posta: ekincorakli@gmail.com

Submitted/Başvuru: 24.08.2020 Revision Requested/ilk Revizyon: 05.11.2020 Last Revision Requested/Son Revizyon: 19.11.2020

Accepted/Kabul: 19.11.2020

Citation/Atıf: Corakli Kahraman, E. (2020). Three Perspectives on the Spiritual Qualities of Music. Konservatoryum - Conservatorium, 7(2), 79-88.

https://doi.org/10.26650/CONS2020-0010

\begin{abstract}
Without containing any verbal or visual concepts, pure music has a deep and immediate power to penetrate into the mind and body. Is it also possible that it provides humans with an awareness of the depths of their nature and of the universe? Can it activate the feeling to be completely free and infinite? In sum, can we attribute to music the power of giving humans spiritual qualities; or to use a better expression, is it possible for humans to discover their spiritual side via musical experience? If the answer is positive, how can it accomplish this mission? In this paper, music's quality as a means for acquiring spiritual qualities will be discussed. The ideas of Arthur Schopenhauer, Andrei Tarkovsky, and Sogyal Rinpoche will guide the discussion. These three people are from different branches; respectively philosophy, cinema and Tibetan Buddhism; which is thought to provide a discussion on the new perspectives about the spiritual qualities of music. Finally, the music type discussed in the paper is pure music, which addresses the music without words, a subject or a visual representation. In order to constitute a base for the discussion, the books of the three scholars were compiled and their thoughts about music were analysed with the document analysis method, which is used in qualitative research. The films of Tarkovsky were additionally analysed with the same method due to his being a visual artist. Keywords: Spirituality, Spirituality in music, Music aesthetics
\end{abstract}

\section{ÖZ}

Saf müzik, herhangi bir sözel veya görsel içeriğe sahip olmadan, zihin ve bedene derin ve anında nüfuz edebilecek bir güce sahiptir. Bu sanat, ayrıca, insanlara kendilerinin ve evrenin doğasının derinliklerine dair bir farkındalık sağlayabilir mi? Ya da bütünüyle özgür ve sonsuz olma duygusunu harekete geçirebilir mi? Özetle, müziğe insanlara ruhani nitelikler verme gücünü ithaf edebilir miyiz; ya da daha doğru bir ifade ile, insanların müzik yoluyla ruhani yanlarını keşfetmeleri mümkün olabilir mi? Bu çalışmada, müziğin ruhani yanı ve ruhani özellikler kazandırmadaki rolü tartışılacaktır. Arthur Schopenhauer, Andrei Tarkovski ve Sogyal Rinpoche bu tartışmaya yön vereceklerdir. Sırasıyla felsefe, sinema ve Tibet Budizmi alanlarında uzmanlaşmış bu üç kişinin müziğin ruhani yanına ilişkin yeni perspektifler sunacakları düşünülmektedir. Son olarak, çalışmada tartışılan müzik; söz, konu veya görsel temsil içermeyen saf müzik ile sınırlıdır. Tartışmaya bir temel oluşturmak için üç düşünürün kitapları derlenmiş ve müziğe ilişkin görüşleri nitel araştırmalarda kullanılan doküman analizi yöntemi ile analiz edilmiştir. Görsel bir sanatçı olması nedeniyle, Tarkovsky'nin filmleri de aynı yöntem ile analiz edilmiştir. Anahtar Kelimeler: Ruhanilik, Müzikte ruhanilik, Müzik estetiği 


\section{Introduction}

In the Cambridge Dictionary of Philosophy, the spirit is defined as the synonym for the word 'soul', which is "an entity supposed to be present in living things", in accordance with its Greek and Latin origins, namely the psyche $e^{1}$ and the anima ${ }^{2}$. This entity, beginning from ancient times, has been accepted as "an immaterial component of an organism" (Audi, 1999, p.866). When it comes to the word 'spiritual', it can be concluded that it means anything which belongs to the spirit, which is the inner and bodiless form of the living things. In our century, as Guillory states, the word spiritual refers to the quality of coming from one's inner self, knowing the inner self and creating inner peace in one's self (Guillory, 2000, p.217).

With its abstract and touching nature, pure music seems to be the most suitable art to be defined as spiritual. Its non-representative and unworldly nature is not only stated in philosophy books but also in some novels or films. In the famous Oscar Wilde novel 'The Picture of Dorian Gray', the character Lord Henry points out that "it is such a blessing for music to be an art which is not imitative" (Wilde, 1890, p.191). The same perspective exists in the novel In Search of Lost Times by Marcel Proust, which stresses pure music's not containing any logical sequences whose deformation causes insanity (Proust, 1992, p.300). In the film 'Tous les Matins du Monde' the genius master of viola, de gamba also makes a brief statement about music, in which he says that music cannot be explained with words as it does not belong to the human world.

Pure music is indeed an art, which doesn't aim at representing any verbal or visual qualities. Its existence is even difficult to describe. Peter Kivy, for instance, emphasizes the ambiguity about its physical being, as it is hard to describe where music is neither by the musical scores which can only provide the sound for the mind of people with musical knowledge nor by the performances which are various and countless (Kivy, 2003, p.203205). Some of the philosophers of music also insist that music cannot possess a clear and fixed physical existence as it can either be found in the mind, in the potential of new performances or in the world of ideas (Popper and Eccles, 1983; Davies, 1991; Kramer, 2007). Then, due to its abstract and ethereal character, we can claim that there may be an acceptable explanation about the effect of music, which can be described via spiritual terms.

1 Psyche (written as $\Psi v \chi \eta ́$ with original Greek letters) means soul and spirit in Greek as well as corresponding to some words such as breath, life, reason and understanding (J. B. Lippincott \& Co, 1855).

2 Anima means soul in Latin as well as corresponding to the words breath, life and ghost (Ørberg, p. 1998). 
Three scholars from the past and today also focused on the mysterious connection between life, humans and music so that the claim above can be grounded firmly and fluent with their contribution. Through this paper, Arthur Schopenhauer will make this contribution with his philosophical view about life and music, while Tarkovsky will provide support with his artistic-spiritual perspective. Finally, Rinpoche will bring in a new spiritual perspective on the topic with his profound knowledge of Tibetan Buddhism. The reason why these scholars are selected to guide the article is that all of them give a special value to music in regard to its spiritual character. Moreover, they are thought to contribute the topic in an original way with their ideas due to their different professions. Their ideas were analysed with the document analysis method, which is an analytical method in qualitative research and "a systematic procedure for reviewing or evaluating documents" (Bowen, p.27).

Schopenhauer as a philosopher, who focused on the metaphysical side of life, is the first scholar to offer ideas about the topic.

\section{Arthur Schopenhauer: A Metaphysical/Philosophical View about Life and Music}

Nearly 200 years ago, Arthur Schopenhauer, in his book 'The World as Will and Representation', presented the idea that the reality of all the universe can only be explained with the metaphysical concept 'will'. The will, for Schopenhauer, is 'the innermost essence, the kernel, of every particular thing and also of the whole" (Schopenhauer, 1969, p.110). However, this essence of the world is not an idealistic one; on the contrary, it is impulsive, imperfect and unrestful. Hence, Schopenhauer defines it as "a blind, irresistible urge which doesn't contain any knowledge" (p.275).

Although the will is an abstract notion, Schopenhauer thinks that we can see kinds of its objectification in the world and in ourselves. For instance, we can observe its appearance in the events of nature and in the actions of humans (Schopenhauer, 1969, p.110). Especially, as humans, we can find the affirmation of will in the endless willing which doesn't contain any knowledge while strongly influencing our lives (p.326). Another way of finding the objectification of will is experiencing the fine art of notes, namely music.

Schopenhauer considers music as the only fine art which has a strong influence on human's innermost nature with its universal language. The reason for this impact is it is the 
copy of the will itself; in other words, it is the essence instead of being only a shadow (Schopenhauer, 1969, p. 256-257). How can music accomplish this task? Schopenhauer explains this with some analogies he draws between the music, the structure of the world and the life of human beings. According to Schopenhauer, the four voices of music, which are respectively bass, tenor, alto and soprano (melody), refers to the degrees of the structure of the world, which are respectively inorganic nature, plants, animals and humans. The bass tones of harmony symbolize the lowest grades of the will's objectification, where everything originates and develops while higher voices represent respectively the plant and animal worlds, and finally, the soprano as the principal voice singing the melody expresses the highest grade of the will's objectification, namely the "intellectual life and endeavour of man". In other words, the melody relates the hidden history of the intellectually enlightened will with depicting all the agitations, struggles and actions of it (p.258259). Therefore, in the journey 1 of melody starting from the deviation of the keynote in the harmonious changes and dissolutions while it proceeds, and in the final return of it to the keynote ; we can experience the suffering of the will from the desire for satisfaction (p.260). This brings us to the famous final quote of Schopenhauer which says: "Music is an unconscious exercise in metaphysics in which the mind does not know it is philosophizing" (p.264). Hence, humans who experience music listening, realize an unconscious trip into themselves, into the world they are living and into the universe. This experience makes them reach to the inner nature of everything, increase and deepen their spiritual level and therefore change their point of view about the world for a while.

Schopenhauer also tries to find the mission of the composer. He depicts the composer as a genius who shows the hidden reality by creating the melody with the help of inspiration (Schopenhauer, 1969, p.260). In other words, he attributes the creator of music the ability to possess the knowledge of the deep truth about the world. However, in parallel with the metaphysical and abstract nature of the will itself, this wisdom does not come from his faculty of reason, therefore it does not include consciousness (p.263).

In a nutshell, Schopenhauer finds the spirituality of music in its power to make human beings feel the inner metaphysical truth of their nature and the universe. Hence, music is a way of experiencing the secret truth of existence which brings the person the wisdom to deviate from the circle of willing and accept life as what it is. The composer, whom Schopenhauer defines as a genius, unconsciously possesses this secret knowledge and conveys it to the audience, who finally reach a more relieved level. 


\section{Andrei Tarkovsky: A Visual/Spiritual View About Life and Music}

The Russian film director Andrei Tarkovsky was one of the most significant figures for 20th- century art house cinema for his unique spiritual point of view. His perspective about music is also worth scrutinizing and discussing. Primarily, we can find some clues for his perspective about music in his first film 'The Steamroller and The Violin' (Tarkovsky, 1961). In this film, music is regarded as something magical and sublime as seen in one of the scenes in which the bullies meet with the violin but cannot dare to give any harm to it because of the enchanted energy it gives.

His deeper views about music can be found in the film 'Stalker' (Tarkovsky, 1979). In one of the scenes, accompanied by the images of the sky and finished on the faces of the listeners; the spiritual protagonist explains his ideas about music as such:

\footnotetext{
"Are you awake? You were talking recently about the meaning... of our... life... unselfishness of art... Let's take music... It's really least of all connected; to say the truth, if it is connected at all, then in an idealess way, mechanically, with an empty sound... Without... without associations... Nonetheless the music miraculously penetrates into the very soul! What is resonating in us in answer to the harmonized noise? And turns it for us into the source of great delight... And unites us, and shakes us? What is its purpose? And, above all, for whom? You will say: for nothing, and... and for nobody, just so. Unselfish. Though it's not so... perhaps... For everything, in the end, has its own meaning... Both the meaning and the cause..." (Tarkovsky, 1979).
}

In the excerpt, Tarkovsky seems to reflect his own ideas about music, which emphasizes that music connects humans with only pure sound, filling the soul profoundly and unselfishly. For him, like every phenomenon in the universe, the unique nature of music has a meaning and a cause.

The response to what the meaning and the cause is can be found in some of his writings and interviews. In his book 'Sculpting in Time', Tarkovsky also emphasizes music's abstract and philosophical character (Tarkovsky, 1986, p.119), its autonomy (p.163), its lack of need for a mediating language due to its direct and emotionally perceived character (p.176) and it's being free from any passions and ideologies (p.177). In an interview, he states that the reason for his quitting music education was music being the highest form of art as it is only perceived on an emotional level. Moreover, it offers sheer 
abstraction, which means "music can utterly express the idea of creation" (Netzeband, 2006, p.39). In other words, music has the quality to reflect the divine action of the creator that explains the existence of the universe and humans.

Digging deeper into his ideas, his full perspective on music becomes more clear. Tarkovsky considers the beauty of music as having a non-logical and a non-mathematical ground, like the beauty of a landscape (Tarkovsky, 1986, p.9). In addition, 'time' is a problem in this art. Hence, the realization of music happens when it completely disappears (p. 63) and it can be played in various ways with different durations (p. 118). Furthermore, like a good film or a painting, good music does not reach the heart with a thought; instead, it is ambiguous and bilateral in a similar vein with life (p.165). And finally, Tarkovsky stresses that Western music is too self-explaining and ambitious compared to Far Eastern music, which does not need/make any effort to explain itself. The main reason for this is the dissolution of the self into God, time, nature etc. and discovery of the inner self of believers in this tradition (p.240).

As written above, Tarkovsky strongly believes in the autonomy and abstractness of music as well as it both having emotional and non-egotistical character. In addition to these qualities, music is so unselfish and lacks ambition that Tarkovsky attributes the spiritual essence of creation to it. This uniqueness and autonomy of music can also be regarded as one of the reasons why he prefers using only natural sounds in his films instead of using special film music.

\section{Sogyal Rinpoche: A Pure Spiritual View About Life and Music}

Sogyal Rinpoche, a teacher of Tibetan Buddhism, is the third person who will contribute to this paper with his ideas. In his famous book Tibetan Book of Living and Dying, he expresses his ideas about life and death with the Tibetan Buddhist perspective. In this book, he especially gives place to music as not only a means for realizing spiritual activities but also as a fundamental concept in some spiritual processes.

Rinpoche thinks that humans have difficulty in becoming aware of the real nature of their minds, which is actually fresh, peaceful and focused on the moment. An exalting piece of music can inspire this as an experience activating illumination, peace and bliss (Rinpoche, 2002, p.51). In the tuning of an instrument, we can even find the clues to create balance for the mind while meditating. Thus, in a dialogue, Rinpoche refers to a 
memory of Buddha with a monk in which Buddha stresses that the best sound of the musical instrument 'vina' emerges when the strings are "neither too taut nor too slack" (p.76). In addition, at the moment of meditating, music can be used as a tool for opening the heart and mind (p.84).

It should be stated here that along with meditation, the belief of reincarnation is one of the most important parts of Tibetan Buddhism. Rinpoche proves the existence of reincarnation with the example of Mozart who composed minuets when he was only five and published sonatas at the age of eight. According to him, Mozart's amazing talent can be attributed to his development in other lives (Rinpoche, 2002, p.92-93).

It is very important in Tibetan thinking to accept death as what it is and not to be afraid of it. Hence, Rinpoche recommends practicing for death, both for the person in the death process and for the ones who are with a person in his death process. Again, in the dying environment, he recommends playing a tape of an exalting piece of music. While the music is being played, he recommends falling asleep to it, waking up to it, dozing toit, etc. and continuing to practice even in dreams (Rinpoche, 2002, p.244-245). Also, based upon the experiences of the people who were near death and later survived, an inner world of preternatural beauty and the feeling of oneness is accompanied by heavenly music (p.325). For instance, a woman stated that at that moment, the sounds were in a new order and harmony, which she called music (p.328).

As seen in the previous paragraphs, in Tibetan Buddhism, music has a significant place in not only meditation practices but also in different dimensions of life and after life. From this point, Rinpoche gets deeper and states that every creative endeavour of humans including music, other arts and scientific discoveries emerges from a mysterious ground of inspiration and is mediated into form by conveying and connecting energy. They, as a result, have an infinite meaning, significance and the power to guide us into a state of contemplation and joy while allowing us to experience the secret of our nature. This brings him to the idea that the creation process may be related with three divine processes of 'bardos', which are stages between death and reincarnation, and which also reveal the actual process of life. These stages are connected with levels of consciousness which are (1) "enfoldment lading to laying bare" (emptiness), (2) "spontaneous radiance" (radiance energy and light) and (3) "crystallization and manifestation" (endless manifestation) The third stage is also defined as the manifestation of enlightenment (in both death and life) 
and Rinpoche thinks that nature of artistic genius derives its inspiration from this dimension. For instance, the masterpieces of Beethoven and Mozart are indicators that these people are channels of enlightened energy. (Rinpoche, 2002, p.346-355).

In sum, Rinpoche regards music as a means for making the meditation and exalting practices deeper and more meaningful. He also interprets music as a creative endeavour spreading and transmitting energy, which makes us contemplate the secret of our nature. In some levels of both life and bardos, the nature of artistic creation receives its inspiration and conveys human beingsenlightened energy.

\section{Conclusion and Discussion}

From the beginning of humanity, there was a need to believe that there is more than what can be viewed or perceived concretely. That's why spiritualism was always part of humans, either with religious beliefs or with the meditative thought and practices to reach the inner self. Pure music, with its abstract and mysterious nature, is thought to be the most convenient art to have a spiritual character.

In this article, three thinkers from different branches were selected to help the discussion about why music can be spiritual. All of them emphasized the transcendental nature of music, however there were subtle differences in their ideas. Along with music's deep and abstract nature, Schopenhauer stressed its philosophizing character due to its utter similarity with the hidden truth. Tarkovsky, with his artistic view, stated especially music's unselfishness and its potential to convey emotions. Rinpoche, as a spiritual teacher, focused on the role of music in spiritual practices and its connection with enlightened energy.

Where they found the spirituality of music is the key point of this paper. Schopenhauer attributed the spirituality of music to its potential to reflect the metaphysical essence of life and humans, namely will. Thus, a person listening to music experiences this fact and becomes aware of this hidden truth. What is will for Schopenhauer is creation for Tarkovsky, who gives music a unique value due to its representing the idea of creation. Finally, Rinpoche stated that musical creation has a relationship with the enlightenment process, therefore it has the ability to possess and reflect the enlightened energy. Although they attribute the spiritual qualities of music to different concepts, they unite in the idea that music reflects the secret essence of the universe and our beings. Due to his lack of belief in religion, Schopenhauer draws the relationship with will; while as a reli- 
gious Orthodox Christian, Tarkovsky connects music with the idea of creation. And finally, as a teacher of Tibetan Buddhism, Rinpoche ascribes the spirituality of music to its presenting the moment of enlightenment in both life and after-life.

Despite the unique parts of their ideas, the views of these three scholars reveal that no matter what their spiritual belief is, a person listening to music runs into the feeling of the inner truth about the universe and himself by unconsciously experiencing what is beyond the visible world. This unique point of music is where we can find a universal kind of spirituality and where we can strengthen the idea that all of us are united intrinsically. Music's spirituality is therefore also a proof for the universality of itself, the profound attachment of humans and the hope that one day all of us will realize this beautiful truth.

The nature of philosophical inspection includes presenting and producing ideas and questions, without an ambition to reach a definite truth. Hence, it is recommended that beyond adding more philosophical inquiries about this topic, there is a need to widen the field of investigation and to do new research in areas such as psychology, sociology and education. Thus, the response to what will end the insensitivity of human life is perhaps hidden in finding the mysteries of spirituality and music.

Hakem Değerlendirmesi: Dış bağımsız.

Çıkar Çatışması: Yazar çıkar çatışması bildirmemiştir.

Finansal Destek: Yazar bu çalışma için finansal destek almadığını beyan etmiştir.

Peer-review: Externally peer-reviewed.

Conflict of Interest: The author has no conflict of interest to declare.

Grant Support: The author declared that this study has received no financial support.

\section{References/Kaynakça}

Audi, R. (1999). Soul. In the Cambridge dictionary of philosophy, Second Edition. UK: Cambridge University Press.

Bowen, G. A. (2009). Document analysis as a qualitative research method. Qualitative Research Journal, 9(2), 2740. DOI 10.3316/QRJ0902027 Erişim adresi: https://www.researchgate.net/publication/240807798

Corneau, A. (Director). (1991). Tous les matins du monde [All the mornings of life] [Film]. BAC Films.

Davies, S. (1991). The ontology of musical works and the authenticity of their performances. Noûs, 25(1), 21-41. DOI: 10.2307/2216091. Erişim adresi: https://www.jstor.org/stable/2216091

Guillory, W. (2000). The living organization: Spirituality in the workplace. USA: Innovations International, Inc., Publishing Division.

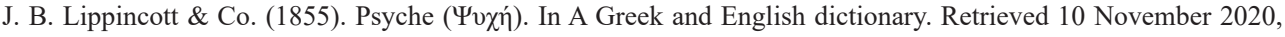
from https://archive.org/stream/greekenglishdi1855 
Kivy, P. (2002). Introduction to a Philosophy of Music. New York: Oxford University Press.

Kramer, L. (2007). Why Classical Music Still Matters. USA: University of California Press.

Netzeband, G. (2006). I love Dovzhenko. In John Gianvito (Ed.), Andrei Tarkovsky interviews (pp. 37-43). USA: University Press of Mississippi.

Ørberg, H. H. (1998). Latin-English vocabulary II. USA: Focus Publishing/R. Pullins Company.

Popper, Karl R. \& Eccles, John C. (1983). The self and its brain. Boston: Routledge.

Proust, Marcel. (1992). In Search of Lost Time, V:1, (C. K. Scott Moncrieff and Terence Kilmartin, trans). New York: The Modern Library.

Rinpoche, S. (2002). The tibetan book of living and dying. USA: Perfectbound/HarperCollins Publishers, Inc.

Schopenhauer, A. (1969). The World as Will and Representation, V:1, (F. J. Payne, Trans.). New York: Dover Publications, Inc. (Original work published 1844).

Tarkovsky, A. (1986). Sculpting in time, (Kitty Hunter-Blair, Trans.). USA: Texas University Press.

Tarkovsky, A. (Director). (1961). Katok i skripka [The steamroller and the violin] [Film]. Mosfilm.

Tarkovsky, A. (Director). (1979). Stalker [Stalker] [Film]. Mosfilm.

Wilde, O. (1890). The picture of Dorian Gray [e-book]. Retrieved from https://www.planetebook.com/free-ebooks/ the-picture-of-dorian-gray.pdf. 